\section{Correlation between the Mechanical Properties and Structural Characteristics of Different Fiber Posts Systems}

Veridiana Resende Novais ${ }^{1}$, Renata Borges Rodrigues ${ }^{1}$, Paulo Cezar Simamoto Júnior $^{2}$, Lourenço Correr-Sobrinho ${ }^{3}$, Carlos José Soares ${ }^{1}$

The aim of this study was to evaluate the flexural strength and flexural modulus of different fiber-reinforcement composite (FRC) posts and determine the correlation between mechanical properties and structural characteristics. Eleven brands of fiber posts were analyzed ( $n=10)$ : Exacto Cônico (Angelus), DT Light SL (VDW), RelyX Fiber Post (3M-Espe), Glassix Radiopaque (Nordim), Para Post Fiber White (Coltène), FRC Postec Plus (Ivoclar), Aestheti-Plus Post (Bisco), Superpost Cônico Estriado (Superdont), Superpost Ultrafine (Superdont), Reforpost (Angelus), and White Post DC (FGM). The posts were loaded in three-point bending test to calculate the flexural strength and flexural modulus using a mechanical testing machine (EMIC $2000 \mathrm{DL}$ ) at $0.5 \mathrm{~mm} / \mathrm{min}$. Data were submitted to oneway ANOVA and Scott-Knot test $(p<0.05)$. The cross-sections of the posts were examined by scanning electron microscopy (SEM). Correlation between the mechanical properties and each of the structural variables was calculated by Pearson's correlation coefficients $(p<0.05)$. The flexural strength values ranged from 493 to $835 \mathrm{MPa}$ and were directly correlated with the fiber/matrix ratio $(p=0.011)$. The flexural modulus ranged from 4500 to $8824 \mathrm{MPa}$ and was inversely correlated with the number of fibers per $\mathrm{mm}^{2}$ of post $(p<0.001)$. It was concluded that the structural characteristics significantly affected the properties of the FRC posts. The structural characteristic and mechanical properties of fiber glass posts are manufacture-dependent. A linear correlation between flexural strength and fiber/matrix ratio, as well as the flexural modulus and the amount of fiber was found.
'Department of Operative Dentistry and Dental Materials, Dental School, UFU - Universidade Federal de Uberlândia, Uberlândia, MG, Brazil ${ }^{2}$ Department of Fixed Prosthodontics, Occlusion and Dental Materials, Dental School, UFU - Universidade Federal de Uberlândia, Uberlândia, MG, Brazil ${ }^{3}$ Department of Dental Materials, UNICAMP - Universidade Estadual de Campinas, Piracicaba, SP, Brazil

Correspondence: Carlos José Soares, Av. Pará, $\mathrm{n}^{\circ} 1720$, Bloco 4L, 38400-902 Uberlândia, MG, Brasil. Tel: +55-34-3218-22-55. e-mail: carlosjsoares@umuarama.ufu.br

Key Words: dental materials, carbon fiber, fiberglass, scanning electron microscopy.

\section{Introduction}

Endodontically treated teeth frequently require post and core restorations for retention purposes because of the extensive structural defects resulting from dental caries and access cavity preparation (1-3). The use of glass fiber posts together with composite resin core foundation materials for the restoration of root filled teeth is now widely accepted as a viable alternative to cast posts and cores $(2,4)$. The major advantage of glass fiber posts is that they have an elastic modulus that is similar to dentin; they utilize low elastic modulus materials, such as glass fiber posts; and they reduce stress arising at the interfaces, enabling the restored system to mimic the mechanical behavior of a natural tooth $(5,6)$.

Fiber-reinforced composite (FRC) posts exhibit biomechanical properties more similar to those of dentin than the metallic posts, creating a homogenous restorative system consisting of post, resin cement and core material along with the tooth substrate (7-10). FRC posts contain a high percentage of continuous reinforcing fibers embedded in a polymer matrix. Because fiber posts are essentially composite materials, their mechanical properties are expected to increase with increasing fiber content $(11,12)$.
There may be a correlation between the mechanical properties and the structural characteristics of posts as regards the post composition. These characteristics include the integrity, size, density and distribution of the fibers as well as the nature of the bond between the matrix and the fibers, which may be the determining factors for different flexure strength values (12-14). The flexural strength of the post could be related to the weak interface bonding between the fiber and matrix, which may be influenced by irregularities produced during the manufacturing process $(12,15)$. Areas of weakness in a FRC post, such as voids present within the resin or in the discontinuities along the interface between the fibers and matrix, may reduce their mechanical properties (11).

It is still not clear how the structural properties of FRC posts influence their mechanical properties (12). Therefore, the present study was conducted to assess the mechanical properties of different FRC posts and to evaluate the correlation between their properties and structural characteristics using scanning electron microscopy (SEM). The tested hypothesis was that the structural characteristics of FRC posts affect their mechanical properties. 


\section{Materials and Methods}

In this study, eleven different brands of FRC posts were evaluated $(n=10)$. The used materials are described in Table 1.

\section{Three-Point Bending Test}

A three-point bending test (Fig. 1) was used to measure the mechanical properties of all specimens in a mechanical testing machine (EMIC DL2000; EMIC, São José dos Pinhais, $\mathrm{PR}$, Brazil) using a $500 \mathrm{~N}$ load cell and $0.5 \mathrm{~mm} / \mathrm{min}$ crosshead speed. The mechanical test consisted of positioning the sample on two supports, which define the length of the

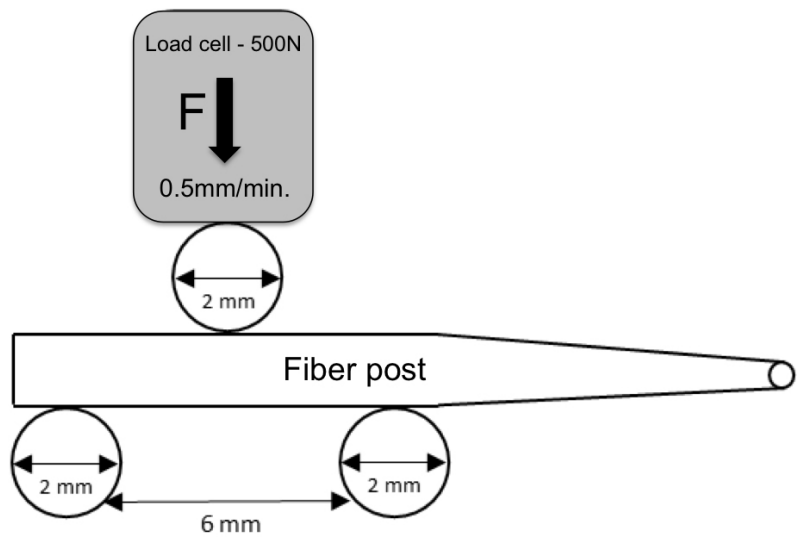

Figure 1. Schematic image of the 3-point bending test used to measure the mechanical properties of tested fiber posts. span distance of the test and applying the vertical load at the mid-point of the specimen (16). The two supports and the central loading rod had a $2.0 \mathrm{~mm}$ cross-sectional diameter. To reduce the influence of the conical end of the posts, the length of the span between the supports was 6.0 $\mathrm{mm}$ to assure testing only on the parallel portion of the post (17). The diameter of each sample was measured at the point where the load was applied using a digital micrometer (Mitutoyo, Japan). The flexural strength $(\sigma)$ and flexural modulus $(\mathrm{E})$ were calculated using the following equations:

$$
\begin{aligned}
& \sigma=8 \mathrm{~F}_{\text {Max }} \mathrm{L} / \pi \mathrm{d}^{3} \text { (in } \mathrm{MPa} \text { ) } \\
& \mathrm{E}=4 \mathrm{~F}_{\mathrm{Max}} \mathrm{L}^{3} /\left(\mathrm{D} 3 \pi \mathrm{d}^{4}\right. \text { ) (in MPa) }
\end{aligned}
$$

where $F_{\text {Max }}$ is the applied load (in Newtons) at the highest point of the load-deflection curve, $L$ is the span length $(6.0 \mathrm{~mm}), d$ is the diameter of the posts (in $\mathrm{mm})$, and $D$ is the deflection (in $\mathrm{mm}$ ) corresponding to load $F$ at a point in the straight-line portion of the curve (16).

\section{Scanning Electron Microscopy (SEM) Evaluation}

All the tested fiber posts were cross-sectioned at the point where the load was applied using a diamond saw (Isomet, Buehler, Lake Bluff, NY, USA). The sectioned surface was embedded in polymethyl methacrylate resin and polished. The finishing was first carried out with silicon carbide paper following the sequence $600,800,1200$, and 1500 grit size under streaming water; the surface was then polished by felt discs with diamond paste. The specimens were ultrasonically cleaned in deionized water for $10 \mathrm{~min}$ and then were mounted on metallic stubs before being sputtered with gold in an ion-sputtering device (Bal-Tec SCD 050, Balzers, Germany). Finally, the specimens were analyzed under a SEM (LEO 435 VP, Carl Zeiss, Germany) at the same magnification $(\times 1000)$

The SEM micrographs of the posts were analyzed using an image processing and analysis program (Image Tool 3.0). The number of fibers and the area occupied by the fibers per square millimeter of the post area were measured.

\section{Statistical Analysis}

Data analysis was performed using one-way ANOVA followed by the multiple comparisons Scott-Knot test at a significance level of $\alpha=0.05$. To verify the correlation between the mechanical properties (flexural strength and flexural modulus), and the structural characteristics (number of fibers per $\mathrm{mm}^{2}$ and fiber/matrix ratio [\%]) for all posts, was used the Pearson's correlation coefficients test at a significance level of $\alpha=0.05$ using a statistical analysis software (SPSS 11 for Windows; SPSS Inc, Chicago, IL, USA).

\begin{tabular}{lccc}
$\begin{array}{l}\text { Aestheti- } \\
\text { Plus Post }\end{array}$ & Bisco; Schaumburg; IL; USA & Quartz & 080011029 \\
$\begin{array}{l}\text { Superpost } \\
\text { Cônico Estriado }\end{array}$ & $\begin{array}{l}\text { Superdont; Rio de } \\
\text { Janeiro; RJ, Brazil }\end{array}$ & Glass & - \\
$\begin{array}{l}\text { Superpost } \\
\text { Ultrafine }\end{array}$ & $\begin{array}{l}\text { Superdont; Rio de } \\
\text { Janeiro; RJ, Brazil }\end{array}$ & Glass & - \\
$\begin{array}{l}\text { Reforpost } \\
\text { Angelus; Londrina; PR, Brazil }\end{array}$ & Glass & 12640 \\
White Post DC & FGM; Joinville;SC, Brazil & Glass & 250209 \\
\hline
\end{tabular}




\section{Results}

Data expressing the correlation between the mechanical properties and structural characteristics are in Table 2. Pearson's correlation test between fiber/matrix ratio $(\%)$ and number of fibers per $\mathrm{mm}^{2}$ of post were used for

Table 2. Mean flexural strength (standard deviations) and fiber/matrix ratio of the tested post systems

\begin{tabular}{|c|c|c|}
\hline FRC Post & $\begin{array}{c}\text { Flexural } \\
\text { Strength (MPa) }\end{array}$ & $\begin{array}{l}\text { Fiber/matrix } \\
\text { ratio }(\%)\end{array}$ \\
\hline Exacto Cônico & $835.9(46.0)^{\mathrm{a}}$ & 68 \\
\hline White Post DC & $822.2(56.0)^{\mathrm{a}}$ & 65 \\
\hline Aestheti-Plus Post & $811.3(42.1)^{\mathrm{a}}$ & 65 \\
\hline Relyx Fiber Post & $805.8(32.7)^{\mathrm{a}}$ & 54 \\
\hline Superpost Ultrafine & $690.1(24.1)^{\mathrm{b}}$ & 62 \\
\hline DT Light SL & $655.8(130.7)^{b}$ & 60 \\
\hline FRC Postec Plus & $632.7(76.7)^{\mathrm{b}}$ & 63 \\
\hline Para Post Fiber White & $627.3(53.3)^{\mathrm{b}}$ & 33 \\
\hline Glassix Radiopaque & $584.9(69.9)^{\mathrm{b}}$ & 61 \\
\hline Reforpost & $569.5(42.0)^{c}$ & 59 \\
\hline Superpost Cônico Estriado & $493.5(49.4)^{\mathrm{c}}$ & 56 \\
\hline
\end{tabular}

Table 3. Mean flexural modulus (standard deviations), structural characteristics and diameter of the evaluated post systems

\begin{tabular}{lccc}
\hline FRC Post & $\begin{array}{c}\text { Flexural } \\
\text { modulus (MPa) }\end{array}$ & $\begin{array}{c}\text { Number of } \\
\text { fibers per total } \\
\text { area of post }\end{array}$ & $\begin{array}{c}\text { Mean post } \\
\text { diameter (mm) }\end{array}$ \\
\hline White Post DC & $8824.3(1011.4)^{\mathrm{a}}$ & 2924 & 1.26 \\
$\begin{array}{l}\text { DT Light SL } \\
\text { Glassix }\end{array}$ & $5594.0(528.4)^{\mathrm{b}}$ & 5116 & 1.48 \\
Radiopaque & $5531.5(778.5)^{\mathrm{b}}$ & 4122 & 1.38 \\
FRC Postec Plus & $5479.2(677.0)^{\mathrm{b}}$ & 7691 & 1.43 \\
Exacto Cônico & $5476.2(365.2)^{\mathrm{b}}$ & 7951 & 1.45 \\
Aestheti-Plus Post & $5288.7(681.6)^{\mathrm{b}}$ & 17452 & 1.40 \\
$\begin{array}{l}\text { Superpost Cônico } \\
\text { Estriado }\end{array}$ & $5181.4(530.5)^{\mathrm{b}}$ & 7427 & 1.48 \\
$\begin{array}{l}\text { Para Post } \\
\text { Fiber White }\end{array}$ & $4957.6(759.8)^{\mathrm{c}}$ & 7547 & 1.41 \\
Relyx Fiber Post & $4924.2(252.0)^{\mathrm{c}}$ & 5326 & 1.56 \\
$\begin{array}{l}\text { Superpost Ultrafine } \\
\text { Reforpost }\end{array}$ & $4830.9(402.2)^{\mathrm{c}}$ & 6645 & 1.49 \\
\hline
\end{tabular}

Same letters in the columns indicate no statistically significant differences between the property values as determined by the Scott-Knot test $(\mathrm{p}<0.05)$. both analyzes, flexural strength and flexural modulus. Significance correlation was observed between fiber/matrix ratio $(\%)$ and flexural strength $(r=0.241 ; p=0.011)$, and between number of fibers per $\mathrm{mm}^{2}$ of post and flexural modulus $(r=0.333 ; p<0.001)$.

The means and standard deviations (SD) of the flexural strength and flexural modulus for the experimental groups are in Tables 2 and 3, respectively. The fiber/matrix ratio (\%) is linear and there was a significant correlation between this ratio and the flexural strength. Multiple comparison tests showed the highest flexural strength obtained for Exacto Cônico and the lowest for Superpost Cônico Estriado (Table 2).

There is a negative correlation between the flexural modulus and number of fibers per total area of post. White Post DC showed the highest modulus, whereas Para Post Fiber White, RelyX Fiber Post, Superpost Ultrafine and Reforpost had statistically similar performances with the highest flexibilities (Table 3).

The post SEM images revealed differences between the tested FRC posts (Fig. 2). Aesthetic-Plus Post (G) had the highest and White Post DC (K) the lowest quantity of fibers. Regarding the fiber/matrix ratio, the highest values were measured in Exacto Cônico (A) and the lowest for Para Post Fiber White (E). A similar pattern of distribution of the fibers was observed for Exacto Cônico (A), RelyX Fiber Post (C), FRC Postec Plus (F), Aestheti-Plus Post (G) and Superpost Ultrafine (I). As regards the bubble presence, Glassix Radiopaque (D), FRC Postec Plus (F), Superpost Cônico Estriado (H) and Reforpost (J) exhibited bubbles in the matrix and at the interface between fiber and resin matrix. RelyX Fiber Post (C), Para Post Fiber White (E), Superpost Ultrafine (I) and White Post DC (K) presented no structural defects and no gaps between the fibers and the resin matrix.

\section{Discussion}

The tested hypothesis was accepted. The structural characteristics affect significantly the mechanical properties of fiber posts. The flexural strength is directly correlated with the fiber/matrix ratio $(p=0.011)$, whereas the flexural modulus is inversely correlated with the number of fibers per $\mathrm{mm}^{2}$ of post $(\mathrm{p}<0.001)$.

Glass, quartz, carbon and ceramic fibers have been used for fabrication of endodontic posts (18). This study evaluated nine brands of glass fiber posts and two of quartz fiber posts, using the three-point bending test. Glass fiber posts exhibited similar values for the flexural strength and flexural modulus compared to quartz fiber posts. Usually, glass fiber posts contain e-glass fibers (electric glass) that 
consist of $\mathrm{SiO}_{2}, \mathrm{CaO}, \mathrm{B}_{2} \mathrm{O}, \mathrm{Al}_{2} \mathrm{O}$, and a few other oxides of alkali metals in the amorphous phase (12). The quartz fiber reinforcement used in DT Light SL and Aestheti-Plus Post is made from pure silica. The elastic modulus of quartz fiber reinforcement does not significantly differ from the other types of glasses, but its low thermal expansion coefficient may be beneficial to the structural integrity during thermal alteration (11).

The addition of fibers to a polymer matrix leads to a significant increase in the physical properties of polymerbased materials. The posts that exhibit a higher fiber/ matrix ratio are be expected to yield a greater fracture resistance (10-12). However, RelyX Fiber Post 4 and Para Post Fiber White had fiber/matrix ratios that were not linearly related to the mean values among the other nine groups tested (Table 2). This variability could most likely be explained by the individual fiber properties contained in each post type. These results show that the fiber density contributes only partially to the mechanical performance of the FRC post (16).

If the bond interface between the fibers and the matrix is inadequate, poor mechanical properties may be expected (19). A better total interface area (fiber and matrix) will result in better mechanical interlocking and increased stiffness (7). This relationship between the interface and stiffness could explain the improvement in the flexural modulus for White Post DC, which presented the highest flexural modulus value and also resulted in low number of fibers, but it had fewer defects from the contact area between the fiber and matrix as shown in Figure $2 \mathrm{~K}$. The correlation between number of fibers and flexural modulus for Reforpost was inversely proportional, and SEM images showed the presence of bubbles and irregularities between the fibers and the matrix (Fig. 2J). In contrast, the Aesthetic-Plus Post had the highest number of fibers and an intermediary flexural modulus value compared with
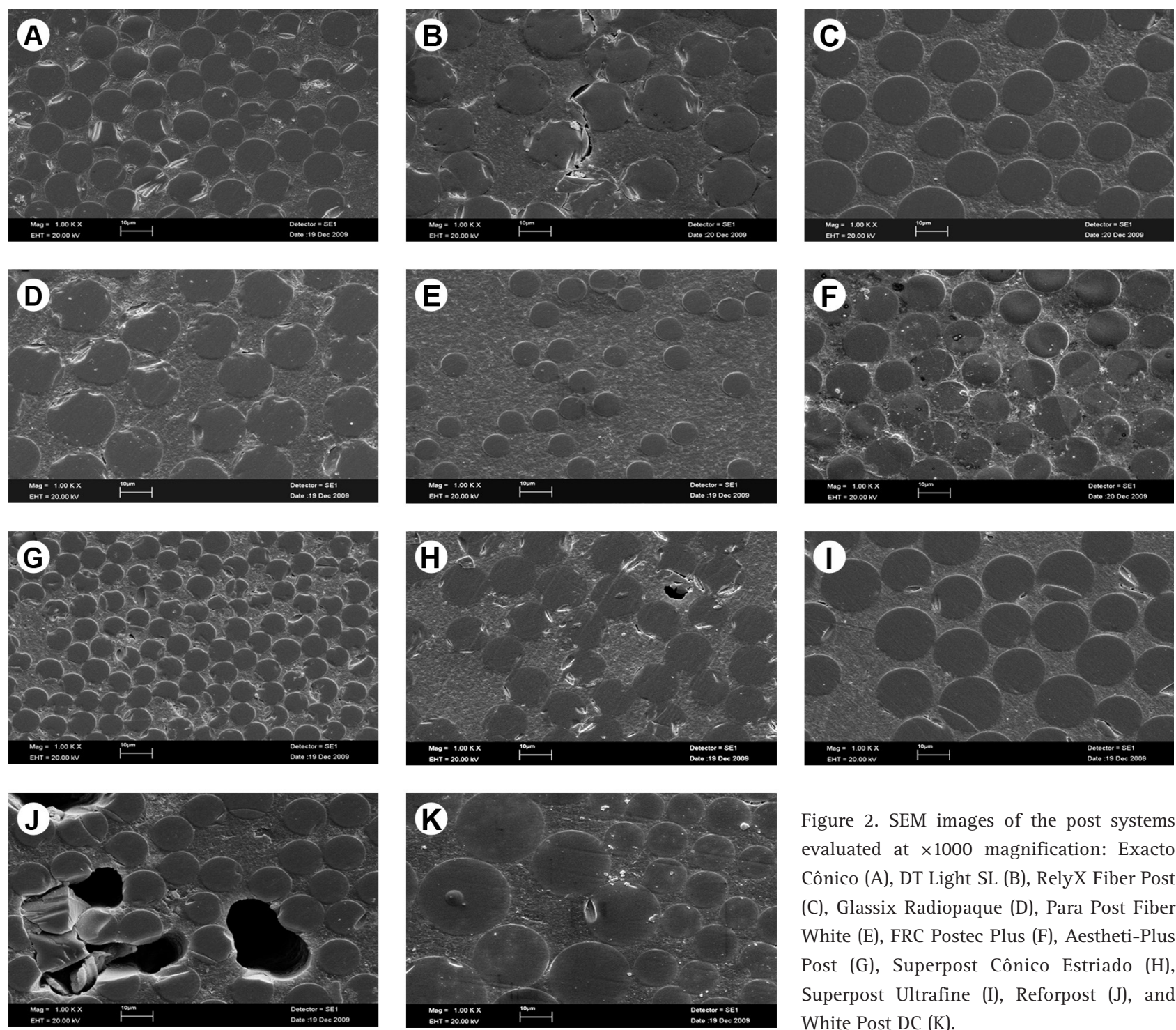

Figure 2. SEM images of the post systems evaluated at $\times 1000$ magnification: Exacto Cônico (A), DT Light SL (B), RelyX Fiber Post (C), Glassix Radiopaque (D), Para Post Fiber White (E), FRC Postec Plus (F), Aestheti-Plus Post (G), Superpost Cônico Estriado (H), Superpost Ultrafine (I), Reforpost (J), and White Post DC (K). 
other groups, demonstrating that the individual properties of the fiber and matrix may be substantial.

The flexural modulus tends to increase with the diameter decrease in the evaluated FRC post systems. Because the three-point bending test is determined by the span distance, the post design and diameter of the post, differences in the diameter may affect the flexural response (19). Composites are recommended, especially for anisotropic FRC with a high $L / d$ ratio (span distance/diameter of post) about $40: 1$ or $60: 1$, to eliminate the shear effect during the bending test (14-17). A lower $\mathrm{L} / \mathrm{d}$ ratio produces more shear deformation in the FRC specimen (18). The engineering material standard of ASTM D 2344 for the short beam test recommends an $\mathrm{L} / \mathrm{d}$ ratio of 4 to determine the interlaminar shear strength of material. Therefore, the $\mathrm{L} / \mathrm{d}$ ratio used in this study was approximately 4.2 , considering a $6.0 \mathrm{~mm}$ span distance and a $1.43 \mathrm{~mm}$ mean diameter values of FRC posts . Apart from the $L / d$ ratio, the higher order diameter term in the expression used to calculate the flexural modulus - $d^{4}\left(4 F_{M a x}{ }^{2} / D 3 \pi d^{4}\right)$ compared to the expression used to calculate the flexural strength $-d^{3}\left(8 \mathrm{~F}_{\mathrm{Max}} \mathrm{L} / \pi d^{3}\right)$ indicates that the flexural modulus has a higher sensitivity to changes in the diameter. White Post DC had the smallest diameter; s nevertheless, it had the highest flexural modulus (Table 3 ).

The FRC post designs may also vary in surface characteristics, such as smooth or serrated surface. Serrated posts have higher retention values and lower rigidity than smooth posts (6). Thus, the addition of a serrated process on the post surface for the purpose of retention, as may be observed in Para Post Fiber White, Superpost Cônico Estriado and Reforpost, could decrease the values of the post's flexural strength due to the discontinuous fibers (11).

Fiber and matrix differences in the FRC posts (volume fraction of fibers, orientation and thickness, bonding to resin matrix, polymerization-induced stress, manufacture process, global integrity of the posts, and intrinsic properties of fibers and matrix) are especially important for understanding the flexural strength and flexural modulus of FRC posts $(11,13,15,20)$. The first concern is that failure results from a small structural defect such as a void or microcrack within the material. Therefore, potential areas of weakness in a fiber-reinforced post should be observed in the voids within the resin or in the discontinuities along the interfaces between the fibers and matrix (6). The Glassix Radiopaque, FRC Postec Plus, Superpost Cônico Estriado and Reforpost had clearly visible empty spaces and bubbles (Figs. 2, D, F, H and J, respectively). On the other hand, voids and bubbles were not visualized for Exacto Cônico, RelyX Fiber Post, and Aesthetic-Plus Post (Figs. 2, A, C and G, respectively), which is most likely the reason for the high flexural strength values of those posts.

Reforpost had the lowest flexural strength; a possible explanation for this could be the weak interface bonding caused by the irregularities and bubbles produced during the manufacturing process (Fig. 2J). Such discontinuities along the interfaces between the matrix and the fibers evidence that interfacial bond strength is critical $(9,21)$. The matrix has a higher thermal expansion coefficient than the glass or quartz fibers which may generate stress and cause adhesive failure between the fibers and the matrix (10). Additionally, due to the different elastic modulus between glass/silica fibers and the resin matrix, stresses normally develop at the interface between the fibers and the matrix and propagate along the surface of the fibers when the posts are loaded (12).

A discontinuity along the interfaces between the fibers and matrix was not observed in the RelyX Fiber Post, Para Post Fiber White, Superpost Ultrafine, and White Post DC posts (Figs. 2, C, E, I and K, respectively). The fact that none of these posts has discontinuity may be due to the combination of the fabrication process for chemical bonding between the fiber and resin matrix and the silanization of the fiber prior to embedding it in the resin matrices. However, much of this information is manufacturing secret $(6,22)$.

The fiber diameters in the Para Post Fiber White (Fig. 2E) and White Post DC (Fig. 2K) were non-homogeneous compared to the other systems. The variation in the diameter of fibers was remarkable; in some cases, there were small diameter fibers located next to areas of large diameter fibers. The Aestheti-Plus Post consists of fibers with diameters much smaller than the other systems (Fig. 2G). However, the flexural strength and flexural modulus were not affected by differences in the fiber diameters of the FRC posts. The type and stiffness of the fiber reinforcement are dominant over the properties of the organic matrix (23). Thus, due to the absence of information from the manufacturer relative to the exact compositions of the type of fiber and polymer matrix makes it difficult to explain the exact reason of these variations in results. Thefore, further studies should be performed to evaluate these questions. However, it is possible to infer that the presence of bubbles is probably related to the manufacturing process during fiber agglutination and also during the cutting process used to prepare the macro-retention on post surface.

A limitation of this investigation is that no thermal cycling or artificial aging of the post systems was performed, as fiber-reinforced composite posts are directly affected by water and changes in temperature (10). In addition, no association was made with the tooth structure. This study was not an assessment of the FRC posts' behavior inside the oral cavity, but instead it reflected the properties of the materials themselves. Thus, further studies should be performed to evaluate the fatigue factors to better understand the effectiveness and durability of the FRC 
posts and to evaluate the behavior of the posts cemented in roots. That type of analysis may help verifying whether the structural defects of the posts affect their long-term use in the clinical setting as well as the stress distribution (24).

In conclusion, this study showed that the structural characteristics affect significantly the mechanical properties of fiber posts. The flexural strength is directly correlated with the fiber/matrix ratio, whereas the flexural modulus is inversely correlated with the number of fibers per $\mathrm{mm}^{2}$ of post. Structural defects such as bubbles and discontinuities along the interface between the matrix and the fibers influence the flexural strength of FRC posts. The flexural modulus and flexural strength are not affected by differences in the diameter of fibers in the FRC posts.

\section{Resumo}

0 objetivo deste estudo foi avaliar a resistência à flexão e módulo de flexão de diferentes pinos reforçados com fibra (PRF) e determinar a correlação entre propriedades mecânicas e caracteristicas estruturais. Foram analisadas onze marcas de pinos de fibra $(n=10)$ : Exacto Cónicos (Angelus), DT Luz SL (VDW), RelyX Fiber Post (3M ESPE), Glassix Radiopaque (Nordim), Pará Publicar Fiber White (Coltène), FRC Postec Plus (Ivoclar), Aestheti-Plus Post (Bisco), Superpost Cónicos Estriado (Superdont), Superpost Ultrafino (Superdont), Reforpost (Angelus), e White Post DC (FGM). Os pinos foram avaliados por meio de ensaio de flexão de três pontos para calcular a resistência à flexão e módulo de flexão utilizando uma máquina de ensaios mecânicos (EMIC 2000 DL) a $0,5 \mathrm{~mm} / \mathrm{min}$. Os dados foram submetidos a ANOVA one-way e teste de Scott-Knot $(p<0,05)$. As secções transversais dos pinos foram examinadas usando microscopia eletrônica de varredura (MEV). A correlação entre as propriedades mecânicas e de cada uma das variáveis estruturais foi calculada por coeficientes de correlação de Pearson $(p<0,05)$. Os valores da resistência à flexão variaram de 493-835 MPa e foram diretamente correlacionados com a proporção de fibra/matriz $(p=0,011)$. 0 módulo de flexão variou de 4500 a $8824 \mathrm{MPa}$ e foi inversamente correlacionado com o número de fibras por $\mathrm{mm}^{2}(p<0,001)$. Concluiu-se que as caracteristicas estruturais afetam de forma significativa as propriedades dos pinos de fibra. As características estruturais e propriedades mecânicas dos pinos de fibra de vidro são dependentes do processo de fabricação. Existe uma correlação linear entre a resistência à flexão e proporção de fibra/matriz, bem como entre o módulo de flexão e a quantidade de fibras.

\section{Acknowledgements}

We thank Professor Elliot W. Kitajima, NAP/MEPA Laboratory, ESALQUSP, for the technical assistance in obtaining the images using scanning electron microscopy (SEM). The authors are indebted for the financial support granted by FAPEMIG and CNPq.

\section{References}

1. Zhu Z, Dong XY, He S, Pan X, Tang L. Effect of post placement on the restoration of endodontically treated teeth: A systematic review. Int J Prosthodont 2015;28:475-483.

2. Valandro LF, Ozcan M, de Melo RM, Galhano GA, Baldissara P, Scotti R, et al.. Effect of silica coating on flexural strength of fiber posts. Int J Prosthodont 2006;19:74-76.

3. Plotino G, Grande NM, Bedini R, Pameijer CH, Somma F. Flexural properties of endodontic posts and human root dentin. Dent Mater 2007:23:1129-1135.

4. Franco EB, Lins do Valle $A$, Pompéia Fraga de Almeida AL, Rubo JH, Pereira JR. Fracture resistance of endodontically treated teeth restored with glass fiber posts of different lengths. J Prosthet Dent 2014;111:3034.
5. Papadogiannis D, Lakes RS, Palaghias G, Papadogiannis Y. Creep and dynamic viscoelastic behavior of endodontic fiber-reinforced composite posts. J Prosthodont Res 2009;53:185-192.

6. Grandini S, Goracci C, Monticelli F, Tay FR, Ferrari M. Fatigue resistance and structural characteristics of fiber posts: three-point bending test and SEM evaluation. Dent Mater 2005;21:75-82.

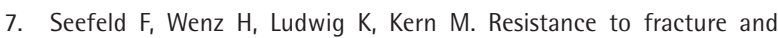
structural characteristics of different fiber reinforced post systems. Dent Mater 2007;23:265-271.

8. Pereira RD, Valdivia A, Bicalho AA, Franco SD, Tantbirojn D, Versluis $A$, et al.. Effect of photoactivation timing on the mechanical properties of resin cements and bond strength of fiberglass post to root dentin. Oper Dent. 2015;40:E206-E221.

9. Cheleux N, Sharrock PJ. Mechanical properties of glass fiber-reinforced endodontic posts. Acta Biomater 2009;5:3224-3230.

10. Novais VR, Versluis A, Correr-Sobrinho L, Soares CJ. Three-point bending testing of fibre posts: critical analysis by finite element analysis. Int Endod J 2011;44:519-524.

11. Asmussen E, Peutzfeldt A, Heitmann T. Stiffness, elastic limit, and strength of newer types of endodontic posts. J Dent 1999;27:275-278.

12. Lassila LV, Tanner J, Le Bell AM, Narva K, Vallittu PK. Flexural properties of fiber reinforced root canal posts. Dent Mater 2004;20:29-36.

13. Wandscher $V F$, Bergoli $C D$, de Oliveira $A F$, Kaizer $O B$, Souto Borges $A L$, Limberguer Ida $F$, et al.. Fatigue surviving, fracture resistance, shear stress and finite element analysis of glass fiber posts with different diameters. J Mech Behav Biomed Mater 2015;43:69-77.

14. ASTM D 790 Plastics (I) Standard test methods for flexural properties of unreinforced and reinforced plastics and electrical insulating materials. Annual book of ASTM standards. American Society for Testing and Materials; 1999

15. Zicari $F$, Coutinho E, Scotti R, Van Meerbeek B, Naert I. Mechanical properties and micro-morphology of fiber posts. Dent Mater 2013;29:45-52.

16. ASTM D 4476, Plastics (III). Standard test method for flexural properties of fiber reinforced pultruded plastic rods. Annual book of ASTM standards, Section 8, Plastics, vol. 8.03: American Society for Testing and Materials; 1999.

17. Cooper G. Optimization of the three-point bend test for fracture energy measurement. J Mater Sci 1977;12:277-289.

18. Parry TV, Wronski A. Kinking and tensile, compressive and interlaminar shear failure in carbon-fibre-reinforced plastic beams tested in flexure. J Mater Sci 1981;2:439-450.

19. Soares CJ, Castro CG, Santos Filho PC, Soares PV, Magalhães D, Martins LR. Two-dimensional FEA of dowels of different compositions and external surface configurations. J Prosthodont. 2009;18:36-42.

20. Grandini S, Chieffi N, Cagidiaco MC, Goracci C, Ferrari M. Fatigue resistance and structural integrity of different types of fiber posts. Dent Mater J 2008;27:687-694.

21. Pereira GK, Lançanova $M$, Wandscher $V F$, Kaizer OB, Limberger I, Özcan $M$, et al.. Fiber-matrix integrity, micromorphology and flexural strength of glass fiber posts: Evaluation of the impact of rotary instruments. J Mech Behav Biomed Mater 2015;48:192-199.

22. Galhano GA, Valandro LF, de Melo RM, Scotti R, Bottino MA. Evaluation of the flexural strength of carbon fiber-, quartz fiber-, and glass fiberbased posts. J Endod 2005;31:209-211.

23. Narva KK, Lassila LV, Vallittu PK. The static strength and modulus of fiber reinforced denture base polymer. Dent Mater 2005;21:421-428.

24. Lazari PC, Oliveira RC, Anchieta RB, Almeida EO, Freitas Junior AC, Kina $S$, et al.. Stress distribution on dentin-cement-post interface varying root canal and glass fiber post diameters. A three-dimensional finite element analysis based on micro-CT data. J Appl Oral Sci. 2013;21:511517. 